\title{
Being first: why the Americans needed it, and why Royal National Park didn't stand in their way
}

\author{
Libby Robin
}

\author{
Fenner School of Environment and Society, Australian National University and the National Museum of \\ Australia Research Centre, Canberra.
}

\begin{abstract}
This is a history of beginnings, but it doesn't come from 1879. Rather it is about the politics of the World Centennial of National Parks in 1972. Not in 1964 - 100 years after the first national park in the world, Yosemite. Nor in 1979 - 100 years after Royal National Park was legislated as the first national park in the world. The politics of the decision to rewrite history to make Yellowstone National Park the signature 'first' national park in the world is entangled with the perception of RNP's history. This decision reveals much about the workings of Earth Day politics in USA in 1970, and also the networks between national parks managers in Australia and in the United States in this period.

The story speaks to the tensions between the national and global in the politics of biological diversity at a time when national parks were seen as the primary solution to a crisis of extinctions. It also reflects the tensions in Australia inherent in the constitutional responsibility for 'national' parks being vested in the states and the issues this still raises for Australia's international responsibilities for global biodiversity.
\end{abstract}

Key words: Royal National Park, Yellowstone National Park, IUCN, UNESCO, National Parks idea, wilderness, nature conservation, World Heritage Convention.

Being first: why the Americans needed it, and why Royal National Park didn't stand in their way

The 1967 National Parks and Wildlife Act in New South Wales is largely based on North American experience and legislation. It is a problem for the future to decide how and where European experience is also relevant.

Leonard Webb (1969: 47-48)

\section{Introduction}

National parks are highly significant models for environmental management. In the present era where conservation is increasingly undertaken with a view to 'benefits beyond boundaries', to use the motto of the Fifth World Congress on National Parks, held in Durban in 2003, the 'National Park' still remains an international ideal. National Parks are, however, rather different in different places because of their varied histories. In some places - but not others - they also have a special relationship with national identity. National parks have been associated for over a century with protecting nature, particularly in the settler societies of Australia, New Zealand, Canada, South Africa and the United States.

The National Parks ideal continues to frame 'good conservation practice', not just in national parks but also in wider systems, such as Australia's National Reserves System (NRS) (Australia 2012a). The NRS includes properties managed privately, under 'publicprivate partnerships' (such as Bush Heritage and the Australian Wildlife Conservancy) (Fitzhardinge 2010) and Indigenous Protected Areas (IPAs), managed by Native Title owners through Aboriginal Corporations (Australia 2012c). Other less prominent patches and fragments of the landscape, sometimes called the 'matrix', are also significant to conservation (Lindenmayer and Fischer 2006), but even so, the original National Parks 'idea' provides an important model in managing biodiversity.
This 'National Parks idea' has been very significant in the perceptions of Royal National Park. This paper is historical, but its focus is not 1879 when the park was first declared, but rather the 1960s, the period leading up to the Royal National Park centenary, where the political context was dominated by the decision to celebrate a World Centennial of National Parks. Why did the organisers of the World Centennial of National Parks decide to base their event to coincide with the centennial of the foundation of Yellowstone in 1972? There were alternative possibilities, even within the United States of America. They could have chosen Yosemite, the first national park in the world, and celebrated a 'World Centennial' in 1964. Or they could have chosen the centenary of the first national park in the world to be legislated as such, which would have put the World Centennial in Australia in Royal National Park in 1979. But it was the centenary of Yellowstone National Park in 1972 that best coincided with celebrating the National Park Idea and the adoption of this concept by global groups such as IUCN.

History was rewritten to suit this moment. In a deal fostered by national parks managers including those in Australia, Yellowstone was lauded as 'first' and the signature national park for the world. By the time of Royal National Park's celebration of its own centenary in 1979, the world national parks moment had passed. Its celebration was merely a local event, a postscript to the moment of the National Parks Idea. 


\section{History of international ideas about nature protection}

At the IUCN's $9^{\text {th }}$ General Assembly in Lucerne, Switzerland in 1966, Professor Jean Baer gave an address (celebrating UNESCO's 20 ${ }^{\text {th }}$ anniversary) in which he traced a history of concern about nature protection rather independent of the National Parks Idea. His story began in 1893, with the ornithologists, "who, because of the existence of migratory birds and the need to protect them, first began to think of these problems in international terms' (Baer, quoted in IUCN 1966: 37). The threat was increasing 'agricultural development'. At the fifth International Congress of Zoology (Berlin) in 1901, Count Berlepsch articulated a concern for 'higher animals which can be considered harmless and which are threatened by extinction because of agricultural development' (Berlepsch quoted by Baer in IUCN 1966: 37). In 1910, the VIII International Congress of Zoology (at Graz, Austria) proposed the first international organisation for nature protection, but it never met because of the outbreak of the war. A second attempt to establish this organisation was made in Paris at the First International Congress on Nature Protection in 1923. A 'London Convention' a decade later formulated precise definitions for international nature reserves and national parks, which were legally accepted at the international level in 1933. IUCN was established in 1948, a time of post-war reconstruction. The IUCN decided to work towards:

The preservation in all parts of the world of wild life and the natural environment, soils, water, forests, including the protection and preservation of areas, objects and fauna and flora having scientific, historic, or aesthetic significance by appropriate legislation such as the establishment of national parks, nature reserves and monuments and wild life refuges, with special regard to the preservation of species threatened with extinction (Article 1, IUCN (Fontainbleau) 1948: 17)

This strongly European model of nature conservation protected what we today would call 'biodiversity', rather than tackling questions of land use. It was not until 1962, a date I return to below, that a Committee of Experts for the Conservation of Nature and Landscape was established by the Council of Europe, with technical advice from the IUCN. In Europe, most forested land was in private hands and governments had less control over its use, so there was not the same opportunity to declare national parks as there was in the New World.

The European model of nature built on expertise in zoology and game management. The North American national parks management tended to employ foresters and ecologists. The national parks of Africa, discussed at length at the First World Conference of National Parks in 1962 where 25 African nations were represented (IUCN (Kenya) 1963), tended to follow the 'game management' model, because of the charismatic game that the parks supported. South African leadership had been important to this, a point commented on in the Kenyan meeting:
'The National Parks Board of South Africa represents one of the pioneer organisations that more than any other has opened now roads and introduced new methods that are today the scientific basis for conservation in Africa' (IUCN (Kenya) 1963: 42-43). But because of the exclusion of South Africa from international diplomatic circles (from 1961 - 1994 because of its Apartheid Government), the game management model became less prominent, leaving a niche for more emphasis on 'wilderness' and land use management through national parks.

All nations recognize that international expectations are embedded in the National Parks Idea and some resisted parks accordingly. When national parks were mooted in Britain in 1930, for example, the Addison Committee preferred the term 'National Reserves' because they felt 'it would be impossible to contemplate game reserves similar to those of Africa and America in a country where the fauna is practically limited to birds, insects and the smaller mammals' (Addison 1930-31: 289). In the 1930s a true national park needed game (for elite sport), whereas Addison was arguing for a system to allow (democratic) access to the countryside. This was the context of the 1933 definition of 'national reserves AND national parks' developed at the London Convention.

\section{The US idea of national parks}

Nationalism in the United States was rather different from Europe, and national parks were accordingly different. Wilderness, the frontier and the West were all tied together in US national identity. Roderick Nash in his Wilderness and the American Mind, first published in 1967, traced a shift in thinking in the 19th century from an earlier fear of wilderness in the Biblical sense to a romanticism and love of wild nature.

Yellowstone National Park became a nationalist symbol of the lost, limitless West. Its first European explorer John Colter was part of the 'Oregon Trail' team, travelling with Lewis and Clark on their epic expedition to the Pacific that opened up the West. The Oregon Trail became the pathway for generations westering after them, and is still celebrated today for its 'pioneer' values through museums, monuments and tourist sites along its path. Colter spent the winter of 1807-1808 in the wilds of what later became Yellowstone National Park. Because he was the first European to see this country, and to spend months alone there, was dubbed the US's 'first mountain man'. Yellowstone National Park thus became iconically linked with ideas of the American West (Dorst 1999: 55-65; Runte 1979: xi-xii). Yellowstone National Park was a concept of people of the West at a time when the Oregon Trail was still carrying people dreaming the dreams of the West to settle on land on the Pacific side of the Rockies. Wyoming represented the mountainous country that was the last major barrier before the West. Wyoming is still the least populous state of the US.

Yellowstone National Park spans 3,472 square miles (almost 9,000 sq kilometres or slightly larger than the total size of Wales) and three states (Wyoming, Montana and Idaho). Most of the park is in the north-west corner of the state of Wyoming, ceded to the United States in 1848 
at the end of the Mexican-American war, so less than a quarter of a century old when Yellowstone National Park was first proposed. Like Yosemite, Yellowstone was initially a local park, with local defenders, but Yellowstone's most passionate advocates lived in the neighbouring state of Montana, not in Wyoming. First they asked the government of Montana to annex the land so that it could be preserved by that state (on the model of Yosemite) under Montana's state law. State borders were arbitrary straight lines, already controversial, so, when moving them was ruled impossible, the activists sought federal legislation for an interstate park (Early 1984: 5-6). The purpose of the 1872 legislation was to preserve the geysers and hot springs of the region and to protect the herds of bison, elk, and other wildlife that inhabited the park. The legislation closed the land to entry under the Homestead Act, mining laws, and other public lands statutes, without formally designating the new land use. The lack of recognition of nature as an 'economic use' was part of what historian Alfred Runte called the idea of national parks as 'worthless lands' (Runte 1984: 48-64).

John Muir, one of the next generation's heroes of wilderness thinking walked the length of the Rocky Mountains from Canada to Mexico, and spent several years living in Yosemite, reflecting on the transformative and transcendental dimensions of wild country. Muir is best known as the founder of America's Sierra Club in 1892. This was just at the time when the frontier to the American West closed (Turner 1893). The limitless opportunities of the West no longer could shape the American dream. Wilderness came to take its place in the American psyche. The Sierra Club campaigned strongly for the 'defense of Yellowstone and Yosemite' (Nash 1982: 132). These were wild places where the American citizen could develop skills of self-reliance celebrated by Muir.

A generation later again, Aldo Leopold, a senior officer in the United States Forest Service who worked in some of the remote forests of New Mexico in the 1920s, used similar arguments about the importance of rugged (virile) recreation in building good national citizens to protect large forested areas from commercial operations. Wild places for nature were also places of personal development in the thinking of both Muir and Leopold. Leopold considered a suitable area to be free of roads and other signs of civilization and big enough to absorb a 'two week pack trip'. (Flader 1994) Leopold laid the foundations for the United States Wilderness Act of 1964, which describes wilderness as an area of land 'retaining its primeval character and influence, without permanent improvements or human habitation'.

It was the westerly gaze of European John Colter from the Lewis and Clark expedition, rather than the many generations of Indian Chiefs who had looked upon the Rocky Mountains, that became entwined into the foundation myths of the Yellowstone National Park. The cultural contribution of indigenous inhabitants was erased in both Yosemite and Yellowstone (Olwig 1995), as part of the construction of a 'wilderness' view of place that suited international objectives for nature conservation in the 1960s.

\section{The IUCN takes a stand on national parks}

In 1958, the sixth IUCN General Assembly adopted Resolution No. 246, recommending that an international list of national parks be established. The IUCN offered its services in the preparation and management of such a list:

- Noting that National Parks and Reserves have been established in most countries that are Members of the United Nations and that they contribute to the inspiration and welfare of mankind, and are internationally recognized as a form of wise land use;

- Believing that these National Parks and Reserves are valuable for cultural, scientific, educational, economic and recreational purposes, and are areas for the future preservation of flora and fauna and geological structure in their natural state, and

- Recognizing that a number of UN bodies, notably UNESCO and FAO, with whom the Union enjoys consultative status, are aware of the essential role of such areas (IUCN (Athens) 1958: 181)

The initial definition of parks for 'recreational' purposes was debated throughout the 1960s - and in 1969, a new definition was adopted which excluded this, leading to discussion about whether it was even appropriate for the IUCN General Assembly to meet in a National Park. Nonetheless the 1972 IUCN meeting went ahead in Banff, then Canada's largest and oldest national park.

Harold Jefferson Coolidge, foundation Vice-president of IUCN, was the leader of the national parks push, convincing the IUCN Board to establish a Provisional Commission on National Parks in 1958. This became a full commission in 1960, with a brief to establish of a UN World List of National Parks and Protected Areas. The IUCN's Commission used the list to bring national parks to the attention of governments worldwide and offered incentives for the creation and maintenance of parks. (Talbot and Talbot n.d.) Coolidge was also a leading organizer of the First World Congress of National Parks held in Seattle, USA in 1962. It was an international meeting of parks managers from 62 nations, sponsored by IUCN and the US National Parks Service together with UNESCO and FAO and had wide influence beyond the US. The European Committee of Experts for the Conservation of Nature and Landscape, established the same year, was a product of this initiative. Key players in the international politics at this time were UNESCO and its consultative partner IUCN, but the American Congress was also important as the 'National Parks Idea' became seen as a nationalist American contribution to the global good. Funding at the IUCN relied heavily on the work of people like Coolidge, who persuaded the US Congress to be generous in support of the National Parks Idea.

Before the IUCN's International Commission on National Parks, one of IUCN's first commissions was its Survival Service (later called the Species Survival Commission), which dealt explicitly with questions of extinction. Although questions of what we would now call 'biodiversity' came first, and were separated from national parks and land for wildlife in the IUCN's organisation, H.J. 
Coolidge was the first Commissioner of both the Survival Service and the subsequent National Parks Commission, and his personal contribution ensured a strong connection between them, if not a full organisational integration within IUCN.

\section{National Parks in the Age of Ecology}

In the period 1966-1969, as the influence of the science of ecology rose, the International Commission on National Parks developed to embrace both species survival and the protection of wild country. It changed from being 'a meeting place for park specialists to a body with a common feeling of responsibility for the last scenic areas and natural habitats of an increasing number of threatened animal and plant species' (IUCN 1969: 117). Shifting the emphasis to international outcomes and the ratifying an international definition of 'national park' through the United Nations official list were ways to support management, without dictating too closely to national governments. The idea of a World Centennial of National Parks built on the United Nations List and served to increase pressure on nations around the globe to reserve land at a time when postwar development had rapidly accelerated, compromising nature in many places. The US Congress was persuaded by Coolidge and others to fund the World Centennial generously because it was persuaded that the National Parks Idea was American and a world-leading concept, good for the nature of the whole planet, that blue globe floating in space recently pictured for the first time by NASA moon missions. The Congress vote was taken in 1970, at the optimistic height of the environmental revolution, the year of Earth Day when environment meant votes, and had just become global. The centennial of the Yellowstone National Park in 1972 was a ripe time to celebrate national parks everywhere. The World Centennial and World Congress were located at Yellowstone and Grand Tetons National Park. International congresses established scientific credentials for national parks and a particular sort of professionalism and expertise in managing agencies and services. The World National Parks Centennial also cemented the peculiarly 'US National Parks idea' into international consciousness. It was a 'jewel in the crown of [American] national achievements', the environmental historian, Roderick Nash commented, likening national parks America's 'other major contributions to world civilization'... 'Coca Cola, Mickey Mouse, basketball and rock 'n' roll' '(Nash 1980: 216). The moral claim of Yellowstone as the world's first national park has framed ideas about national parks, wilderness, conservation and biodiversity well beyond the cultural context of the United States.

\section{Yellowstone - iconic but not first}

Yellowstone was not the world's first national park, or even first in the United States. The National Park at Yosemite, created eight years earlier in 1864 as a State Park for the people of California, was just as much a national park in the sense of being a 'big and wild' nature reserve. If it was so important to be first, why was it Yellowstone and not Yosemite that was the celebrated basis for the
National Parks Idea? There were three reasons. The first was that its timing was wrong, 1964 was too early for the World Centennial political momentum. The second was technical, Yosemite's managing bureaucracy was not 'national' (until 1890). Politically, however, the most important reason for the choice was Yellowstone's symbolic association with the American West. The cultural significance of Yellowstone, not its natural significance, inspired Congress to support the World Centennial on Yellowstone.

While the US Congress may have been persuaded by such cultural arguments, the rest of the world focused on the sheer extent and wildness of the country. Natural and wild were international categories, not specific to individual nations; indeed, the fact that they excluded the human influence reinforced these ideals as 'above the cultural'. It also reinforced scientific managers as 'experts' on national parks, particularly those whose science focused on biological diversity. From the early twentieth century onwards, Yellowstone National Park offered a benchmark for local activists working towards excellent large parks in a wide range of places throughout much of the century since 1872. This undoubtedly justified its celebration as the hub of the 'national parks idea' at the time. Take for example, Canada, which argued for the enlargement of the Rocky Mountains (later Banff) National Park in 1902 explicitly using its unfavourable comparison with the size of Yellowstone (Lothian 1987: 32). Banff's initial 673 square kilometres was expanded to 11,396 square kilometres, a very significant size, just a bit larger than Yellowstone. Wildness continued to be valued in neighbouring Canada beyond the centennial. J G Nelson, for example, commented in 1978 that 'ideally a national park contains few signs of man'. (Nelson et al. 1978: 5)

In the new Republic of South Africa in 1907, the Transvaal Legislative Council debated the future of the reserve that would become part of Kruger National Park. The politicians were urged to aim for something extensive 'like the Yellowstone National Park' (Carruthers 1995: 45). It was a model at a time when there were few parks internationally, but a number of nations were considering them. Europe's first national parks were in Sweden in 1909 (Grundsten 1987).

Closer to home we find an activist for a National Park at Wilsons Promontory in Victoria in 1904 asking 'Why not take a lesson from the Yellowstone reserve in America?' (Anon 1904: 84). Australian nationalist rhetoric accompanied the plea:

Scarcely any other civilized country under the face of the sun has done less in the way of preserving the original fauna and flora than Australia. We are really behind the English-speaking and even the Japanese race. New South Wales and New Zealand are the only honourable exceptions in our group. (Anon 1904: 84)

A significant part of the World Centennial celebration concerned these sorts of examples of Yellowstone's influence, spurring nationalistic efforts towards reserving large areas for nature all around the world including within the United States itself. The Centennial was thus not about Yellowstone's complex early history, but rather 
its symbolic role in a century of national parks. The definition of the national park - what was seen to be of value - was, however, closely tied to the particular ideal that was seen as desirable in 1970.

\section{Royal National Park and Yellowstone}

It was very late in the planning for the World Centennial before the organizers discovered that Yellowstone was not strictly a 'national park' in 1872. The legislation that reserved the Yellowstone area never used the term 'national park'. Roderick Nash found evidence of the term in newspapers such as the New York Times and by the Acting Secretary of the Interior in 1872. It was used in a civil appropriations bill in 1878 . But neither the discussions in Congress leading up to the bill, nor the crucial legislation for Yellowstone used the term 'national park' (Nash 1980: 225). This detail has become blurred since (see for example Grey n.d.), but in the early 1970s, it was a great embarrassment. Indeed the earliest formal legislation for a national park in the United States was not until the creation of Mt Rainier National Park in 1899, by which time New South Wales ((Royal) National Park 1879, Ku-ring-gai Chase 1891), South Australia (Belair 1891), New Zealand (Tongariro 1884) and Canada (Rocky Mountains (later Banff) 1885) all had formally legislated national parks. The United States, on this reading, was not first at all.

Although the first 'national park' legislation in the world was passed in New South Wales on 31 March 1879, New South Wales parks managers did not want Royal National Park to be regarded as a 'world first'. It lacked the international distinction of the bigger, wilder Yellowstone. Roderick Nash wrote that this was a great relief to the 'red faced' planners of the American Centennial that the Australians did not press their claim (Nash 1980: 216-218). New South Wales parks managers were not just being courteous. Defending the status of Royal National Park as the 'first national park in history' was to redefine what a national park meant at a time when New South Wales had just passed legislation, the National Parks and Wildlife Act (1967), modelled closely on North American experience. Its new National Parks and Wildlife Service (established in 1967, through the Act) was directed by Samuel Weems, an American appointed to New South Wales directly from being Parks Adviser to the United States Department of the Interior. The American model was considered 'best practice' at the time, and alternative models were rarely canvassed. One exception was forest ecologist Len Webb, who undertook an independent tour of European national parks and nature reserves, and recognised that these were rather different. He pondered presciently that National Parks managers of the future may have to decide 'how and where European experience is also relevant' (Webb 1969: 48).

New South Wales parks managers wanted the world centennial of the 'National Parks Idea' to honour large wild parks, not urban-fringe reserves. There were already much larger, wilder and more ecologically diverse reserves elsewhere in the state, and the Yellowstone model was relevant to these. Royal National Park was compromised for them by its proximity to Sydney. The National Park (which became known as the Royal National Park in 1955 to honour the visit of the Queen) was originally set aside under a very different vision. It was a green space for crowded urban slum-dwellers, a Hampstead Heath (Readers Digest 1987: 31) or a 'Hyde Park of the bush' (Turner unpub. 1979), a term used by one activist in 1879 . This was a national park just twenty kilometres from a major city, based on the model of the British urban park (Hampstead Heath, Hyde Park), nothing like Yellowstone National Park, 1600 kilometres from any city.

The National Park is a better example of the 'Octavia Hill idea' than the Yellowstone model. In 1895, Octavia Hill founded the National Trust for Places of Historic Interest or Natural Beauty in England and fought for green spaces in and around cities on social, not ecological, grounds (Weideger 1994). Her concerns about 'lungs' for the city and opportunities for 'slum dwellers' were echoed in the early ideas about the National Park in Sydney, even in the rhetoric. Several influential 'public-minded' denizens of Sydney, most notably Sir John Robertson, famous NSW land reformer and first trustee of the National Park (Nairn 1976), asked the government to support the reservation in 1879. It was part of a campaign for 'public parks, pleasure grounds and places of recreation adjacent to all thickly populated centres' (Official Guide 1894, cited in Goldstein 1991: 162).

The centenary history of Royal National Park was critical and anything but celebratory. The park was far from ideal in a state that, by 1979, had many bigger and better ones. The Royal National Park's twentieth century historians regretted its proximity to the suburbs and its extensive use by people in accordance with its original nineteenth century purpose:

[The Park]...was still a major recreation area, increasingly popular with ethnic groups who were concentrating in suburbs adjacent to the park. Its popularity testified to the wisdom of Sir John Robertson's original proposal. One hundred years later he would still recognise his park and take satisfaction from its use. (Pettigrew and Lyons 1979: 30)

This was just a local centenary, not an international celebration of national parks. Adherence to an original vision was not as worthwhile as participating in the National Park ideal of nature and wilderness preservation for its own sake.

Centenaries and celebrations are almost always more about the present than the past. The centenary of national parks in New Zealand in 1987 focused on Tongariro National Park, the first in New Zealand's national park system, and celebrated the politically important Maori contribution, 'the gift by Te Heuheu Tukino IV of the three mountain peaks which formed the nucleus of Tongariro National Park' (Eldridge 1989: 14). An international partnership in national parks was also part of the celebration. Yellowstone National Park USA sent a plaque which was unveiled at the event, congratulating 
New Zealanders on 100 years of national parks. 'Being first' justified an international honour to be bestowed not by the UN or IUCN, but by an individual park in the USA. This honour was not bestowed on Royal National Park in 1979, perhaps because it was regarded as too unlike the 'ideal', or perhaps because there was still anxiety about Yellowstone's own status as 'first' with respect to Royal National Park in the 1970s.

Being first was not always an advantage for Yellowstone National Park itself. It froze the idea of what the park was, and what management ought to do there, making criticism and change difficult as priorities changed in later years. Alston Chase suggested in his provocatively titled book, Playing God in Yellowstone that Yellowstone was dying as a wildlife refuge:

the park's reputation as a great game sanctuary is perhaps the best-sustained myth in American conservation history and the story of its decline perhaps one of our government's best-kept secrets. (Chase 1986: 6)

Within the United States, Yellowstone's international reputation silenced domestic conversations about how it should be managed in the decade following the World Centennial, though its biodiversity conservation situation has improved significantly in the twenty-first century (Figgis, pers. com, visit 2008).

\section{Culture of wilderness, frontiers and national parks}

In Australia, frontier myths are different. The frontier never closed. Australian heroes often die in the bush (Rose 2004). Although the people are heroic, the frontier itself is not a singular place that is the focus of desirable recreation or citizenly greatness as the Oregon Trail symbolized in the United States. Australian-style bushwalking is not so much a celebration of rugged individualism as a means to appreciate nature and escape the city (Harper 2007). It has a more European sensibility and an emphasis on natural history, and later science rather than on romantic transcendentalism and poetics that drive ideas of wild country. In the United States where big game hunting was promoted as a citizen's right, wild country was allied with freedom and sometimes capitalist dreams, particularly in the Cold War years. In Australia, where the 'big game' had never attracted fee-paying trophy hunters, the appreciation of nature was different. Our first 'bushwalking craze' came in the 1930s at a time when people were looking for inexpensive pastimes that could help them escape a depressed economy (Harper 2007). As in America, Australian bushwalkers undertook feats of endurance, but for different reasons. The architect Myles Dunphy and his wife, Margaret, for example, pushed their baby son Milo up the fearsome Mt Kanangra in New South Wales in a large pram in 1931. (Meredith 1998) Dunphy was well known for promoting 'Primitive Areas', wild places where one can rid oneself of the 'shackles of ordered existence... to escape' civilization, but he did not tie this to national frontier mythologies, nor to religious or transcendental feelings, like those of John Muir or Henry Thoreau, as they did in the USA. Indeed the idea of
Primitive Areas did not go beyond New South Wales (apart from more recent (international) legislation for 'scientific reference areas', which are clearly motivated by science, not religion). Nonetheless, enthusiasm for bushwalking was complemented by a growing interest in increasing the size of national parks in most Australian states from the 1960s onwards particularly. Despite the bushwalking craze, national parks were most often defended for their flora, fauna and scenery rather than for human solace.

By the late 1960s, another sensibility was emerging. The Lithuanian Australian photographer Olegas Truchanas took his camera in a home-made yellow canoe to the wilds of southwest Tasmania. His beautiful and well-known images brought a new sort of appreciation of inaccessible Tasmanian landscapes, and drove the 'environmental' protest movements for Lake Pedder and the Franklin River. The first campaign was perhaps lost because it 'wilderness thinking' had not yet developed a following in Australia. Before the international Earth Day in 1970, conservation was the province of natural history, rather than environmental (or green) politics (Robin 1998). This was true in Sweden as well as Australia (Beckman 2011). By the late 1970s after the World Centennial and international influence of the National Parks ideal - and just as Royal National Park was celebrating its own centenary - wilderness was gaining a high political profile, and a green environmental movement to support its preservation. It was this new wilderness momentum that stopped the Franklin Dam in 1983. (Bonyhady 1993) The Truchanas canoe is now in the National Historical Collection at the National Museum of Australia, a symbol of this national shift in environmental consciousness. (NMA 2012).

IUCN initiatives shaped Australia's approach to national parks in the 1960s and 1970s. A 1960 Report by the Commonwealth Attorney-General's Department listed only Victoria, Tasmania and Queensland as having National Parks Authorities, and commented that a National Parks Service was not provided in any State. The IUCN urged management by 'the highest competent authority' in the country (IUCN 1975), but in Australia, national parks were a privilege of statehood, and states were reluctant to relinquish this. Nonetheless, the Australian Academy of Science attempted a national approach to national parks that strongly advocated ecological survey work to ensure that at least some of all ecosystem types were represented in national parks and reserves (Robin 1994). This work endorsed that notion that qualified ecologists were essential to the design and management of national parks. Almost all worked in state-based agencies and only in rare cases with their interstate counterparts. One exception was the Australian Alps Liaison Committee that worked to span three jurisdictions, including the Australian Capital Territory, where the federal government took co-ordinating responsibility. (Robin and Griffiths 1994)

Since the mid-1980s, new cultural movements have changed the scene in nature protection. The Indigenous land rights movement, both in Australia and internationally, added concern about human rights and justice in relation to environmental management. Australia 
took an international leadership role in developing models for joint management (and co-management) of national parks. Beginning with Kakadu and Uluru-Kata Tjuta in the Northern Territory in the 1980s, it became increasingly normal for Aboriginal communities to co-manage and be represented on boards of management in national parks. (Lawrence 2000: 181-192). New South Wales has been a leader among the states, which now have joint management arrangements in many more national parks (Fleming unpub. 2000, Figgis 1999).

The IUCN's 1992 World Protected Areas Congress in Venezuela produced the Caracas Declaration that advises managers of national parks and protected areas to act in a 'manner sensitive to the needs and concerns of local people' (Lawrence 2000: 175). Following the Mabo judgement in 1992 (the same year as the Caracas Declaration), a further revolution has occurred, in significant Native Title determinations. Much of these privately owned areas are now reserved as Indigenous Protected Areas (IPAs) (Figgis 1999).

Australia's National Reserve System (NRS) is now 'the nation's premier investment in biodiversity conservation' (nearly 10,000 protected areas covering over 103 million hectares (Australia 2012a). The NRS is a new scale of nature protection, and includes very different experts. NRS work is funded by governments, multinational corporations and environmental philanthropy (Altman 2011: 128). A quarter of the area of the NRS is Indigenous Protected Areas (51 of them, covering over 360,000 sq. kilometres, Australia 2012c ) - this total is more than 40 times the area of Yellowstone National Park. Aboriginal management includes cultural values (caring for country) and community health, as well as biodiversity values. Biodiversity management offers Aboriginal livelihoods in remote places. Native title ownerships and the capacity to include other privately-owned reserves in the 'conservation system', including working agricultural properties, have redefined biodiversity management, moving the emphasis away from state 'ownership', wilderness and national symbolism, to an emphasis on caring for ecosystems and whole landscapes, irrespective of property arrangements. People are now deemed 'good for biodiversity'. This is something Aboriginal activists have argued consistently but in the 1970s forums dominated by wilderness ideas, it was harder to argue that the presence of people was positive (Head 2000, Langton 1998). Now, conservationists agree that respecting culture can be positively helpful to conservation (Muir, Rose and Sullivan 2011). The management of weeds and feral animals is very much a concern across depopulated areas in remote Australia, shared by farmers, traditional owners and those focused more on natural ecosystem recovery. But these changes that embrace cultural values as valuable to biodiversity conservation have taken many years. The Linnean Society of NSW conference on the natural history of Royal National Park (held at Kamay Botany Bay National Park) on 29 September 2011 opened with a Welcome to Country by Aboriginal elder Dean Kelly. Such a start would have been inconceivable at the time of the Centenary of Royal National Park in 1979.

\section{World Heritage}

The National Parks Idea was one of the great ideas of the twentieth century, but not the only one for nature protection, and not always the appropriate one everywhere. The model of Yellowstone - a singular national park celebrated for its wilderness values - has been useful, but iconic singularities also introduce problems. Ecologies themselves are no longer 'fixed for all time' in place as they respond dynamically to climate change, for example. Where boundaries are no longer fixed, the areas beyond boundaries are even more important, as stresses on ecosystems come from all around. (Lindenmayer and Fischer, 2006). Another international model, World Heritage, considers western cultural traditions and protecting 'human' landscapes and the sense of place associated with livelihoods. World Heritage is more closely allied with the European nature protection traditions observed by Len Webb in 1969.

The 1972 United Nations conference on the human environment in Stockholm, as part of its declaration, recommended Nature conservation, including wildlife, must ...receive importance in planning for economic development' (United Nations Environment Programme: Declaration, Principle 4). UNESCO's World Heritage Convention was signed in Paris the same year. The World Heritage Convention was the first international convention where culture and natural history were valued together as a single phenomenon, as their economic development became united through tourism. It predated 'sustainable development', but had elements of the 'triple bottom line accounting' that came to the forefront at the Rio Earth Summit in 1992. As the World Heritage Convention approaches its $40^{\text {th }}$ anniversary in 2012, the List of World Heritage now numbers 936 sites of which slightly less than 20\% (183) are natural sites. Internationally there are with 2\% (28) 'mixed' and 78\% (725) cultural sites.

Because of its 1970s history, Australia's profile is very different from the typical international balance. Most of its nineteen World Heritage Sites were listed as natural or mixed landscapes. 'Cultural only' sites are the exceptions. There are just two buildings on the list, the Melbourne Exhibition Building (2004) and the Sydney Opera House (2007). Its earliest nominations, Great Barrier Reef, Kakadu and Lord Howe Island, were all signature 'natural' heritage. Kakadu's Indigenous cultural values were also recognised, and its archaeological significance as the site of Australia's earliest documented human habitation $(55,000$ years at Malakunanja II) (Roberts, Jones and Smith 1990).

Australia is well represented in World Heritage for large remote areas, but its large cities are not prominent. The Greater Blue Mountains World Heritage area (declared in 2000) is not far from Sydney, but is promoted as follows: 'The unique plants and animals that live here relate an extraordinary story of the evolution of Australia's unique eucalypt vegetation and its associated communities, plants and animals. It is an area of breathtaking views, rugged tablelands, sheer cliffs, deep, inaccessible valleys and swamps' (Australia 2012 b). 
The discovery of the Wollemi Pine was central to the nomination, although Aboriginal and settler cultural values and proximity to Sydney were part of its status as a 'mixed' site. Urban heritage is generally regarded as cultural, not natural. Royal National Park, with its extensive 'unspoiled' areas (this is the term used in English and Welsh National Parks since the 1940s), and its proximity to a major city could potentially represent a further dimension to urban World Heritage, and one that could also continue to build its relations with Aboriginal and non-Aboriginal community cultural values, as well as support biodiversity values in urban environments.

Former United Nations Secretary General Maurice Strong suggested at the 1992 Rio Summit (United Nations Conference on Environment and Development) that the battle for sustainability will be won or lost in the cities. (Clark 2003: 1). This statement has spurred a growth in urban ecology in the 20 years since. Cities are increasingly where most people in the world live, particularly so in Australia, and this trend is predicted to accelerate over the next half century. There is a renewed international interest in the biodiversity of cities - with new estimates of up to $50 \%$ of the world's biodiversity being found inside city limits. (Clark 2003). Perhaps what Royal National Park could celebrate more is its own history of another 'national park idea', of green space in the city. Rather than regretting its inferiority to the (Yellowstone) National Park Idea, Royal National Park could promote its original vision as a world first in what we now call Urban Biodiversity management. (Grimm et al. 2008).

\section{Acknowledgements}

I would like to acknowledge the helpful comments made on earlier drafts of this paper by Xuemei Bai, Jane Carruthers, Robert Crombie, Kirsty Douglas,
Penny Figgis, Dan Lunney and Geoff Mosley, and the anonymous referees for Australian Zoologist

\section{References}

[Addison Report] [UK] Report of the National Parks Committee Parliamentary Papers 1930-31, Cmd 3851, xvi, 283-414.

Anon. 1904. Emu, 4(2) (October 1904), 84.

Australia 2012a. Department of Sustainability, Environment, Water, Population and Communities: National Reserves System (NRS) http://www.environment.gov.au/parks/nrs/index.html (accessed 11 August 2012)

Australia 2012b. Department of Sustainability, Environment, Water, Population and Communities: Heritage (World Heritage), 'Greater Blue Mountains' http:/www.environment.gov.au/heritage/places/ world/blue-mountains/index.html (accessed11 August 2012).

Australia 2012c. Department of Sustainability, Environment, Water, Population and Communities: Heritage (World Heritage), 'Indigenous Protected Areas' http://www.environment.gov.au/ indigenous/ipa/index.html (accessed11 August 2012)Beckman, Jenny 2011. "Biodiversity as species protection: The Swedish Species Information Centre and its histories" Presentation at Sigtuna conference on Environmental Humanities Sweden, September 2011.

Bonyhady, Tim 1993. Places Worth Keeping. Sydney: Allen and Unwin.

Carruthers, Jane 1995. The Kruger National Park, Pietermaritzburg: University of Natal Press.

Chase, Alston 1986. Playing God in Yellowstone: The destruction of America's first National Park, Boston and New York: The Atlantic Monthly Press

Clark, W.C., 2003. Editorial: Urban environments: battlegrounds for global sustainability. Environment 45(7), September, 1.

Dorst, John D. 1999. Looking West, Philadelphia: University of Pennsylvania Press

Early, Katherine E. 1984. 'For the benefit and enjoyment of the people': Cultural attitudes and the establishment of Yellowstone National Park, Washington DC: Georgetown University Press.

Eldridge, Margaret 1989. Final Report of the National Parks Centennial Commission, Wellington: Department of Conservation, July.
Figgis, Penny, AM. 1999. Australia's National Parks and Protected Areas: Future Directions. A Discussion Paper. ACIUCN Occasional Paper No. 8. Sydney: IUCN Australian Committee.

Fitzhardinge, Guy, 2010. 'Production Lands, Philanthropy and Biodiversity', in Robin, Libby, Chris Dickman and Mandy Martin (eds). Desert Channels: The Impulse to Conserve Melbourne: CSIRO Publishing: 284-299.

Flader, Susan L. 1994. Thinking Like a Mountain: Aldo Leopold and the Evolution of an Ecological Attitude toward Deer, Wolves, and Forests. Madison: University of Wisconsin Press.

Fleming, Tony [unpub. 2000]. 'New directions for Parks and Wildlife in Southeastern NSW', Unpublished Seminar, Environment Institute of Australia, Canberra, 17 May 2000.

[Goldstein, Wendy] 1991. Royal National Park, Sydney: NSW National Parks and Wildlife Service (first edition 1976)

Grey, Brian E. n.d. 'Yellowstone National Park Act (1872)' http://www.enotes.com/major-acts-congress/yellowstonenational-park-act (accessed 23 September 2009Grimm, Nancy B., Stanley H. Faeth, Nancy E. Golubiewski, Charles L. Redman, Jianguo Wu, Xuemei Bai and John M. Briggs, 2008. 'Global Change and the Ecology of Cities', Science 8 February 2008: 319 (5864): 756-760 DOI: 10.1126/science. 1150195.

Grundsten, Claes 1987. National Parks in Sweden: Europe's Last Wilderness, (2 ${ }^{\text {nd }}$ Ed.) Stockholm: National Environmental Protection Board.

Harper, Melissa 2007. The Ways of the Bushwalker: On Foot in Australia, Sydney: UNSW Press.

Head, Lesley 2000. Second Nature: The History and Implications of Australia as Aboriginal Landscape, Syracuse NY: Syracuse University Press.

IUCN General Assembly http://www.iucn.org/2012_congress_ old/past_congresses_and_general_assemblies/\# allproceed)

1948 Fontainebleu http://data.iucn.org/dbtw-wpd/edocs/1948001.pdf

1958 Athens

1960 Warsaw http://data.iucn.org/dbtw-wpd/edocs/GA-7th-006.pdf 
1963 Nairobi, Kenya http://data.iucn.org/dbtw-wpd/edocs/ NS-SP-001.pdf

1966 Lucerne http://data.iucn.org/dbtw-wpd/edocs/NS-SP-008.pdf

1969 New Delhi http://data.iucn.org/dbtw-wpd/edocs/NS-SP027.pdf

IUCN 1975. World Directory of National Parks and Other Protected Areas, IUCN, Morges, Switzerland,

Langton, Marcia, 1998. Burning Questions: Emerging Environmental Issues for Indigenous Peoples in Northern Australia, Darwin: Centre for Indigenous Natural and Cultural Resource Management, Northern Territory University.

Lawrence, David 2000. Kakadu: the Making of a National Park, Carlton South: The Miegunyah Press.

Lindenmayer, David B. and Joern Fischer 2006. Habitat fragmentation and landscape change: an ecological and conservation synthesis, Washington DC: Island Press.

Lothian, W. F. 1987. A Brief History of Canada's National Parks Ottawa: Ministry of Supply and Services, 1987

Meredith, Peter 1998. Myles and Milo Sydney: Allen and Unwin.

Muir, Cameron, Deborah Bird Rose and Phillip Sullivan, 2010. 'From the other side of the knowledge frontier: Indigenous knowledge, social-ecological relationships and new perspectives', The Rangeland Journal, 32: 259-265

Nairn, Bede 1976. 'Robertson, Sir John (1816-1891)', Australian Dictionary of Biography, National Centre of Biography, Australian National University, http://adb.anu.edu. au/biography/robertson-sir-john-4490/text7337, accessed 22 September 2011.

Nash, Roderick 1980 'The Confusing Birth of National Parks', Michigan Quarterly Review, 19, pp. 211-20.

Nash, Roderick 1982. Wilderness and the American mind, Yale University Press, 1982. ( $1^{\text {st }}$ ed. 1967).

Nelson, J.G., R. D. Needham and D. L. Mann (eds.) 1978. International experience with National Parks and related reserves, Ontario: University of Waterloo.

NMA (National Museum of Australia) 2012 online. 'How do Museums Represent History' (Case Study 2, p. 9). http:/ www.nma.gov.au/ data/assets/pdf file/0019/19081/Museums represent_full_colour.pdf (accessed 12 August 2012).
Olwig, Kenneth R. 1995. 'Reinventing Common Nature: Yosemite and Mount Rushmore-a Meandering Tale of Double Trouble' in William Cronon (ed.) Uncommon Ground: Toward reinventing nature, New York: WW Norton and Co., pp. 379-408.

Pettigrew, Carolyn and Mark Lyons, 1979, 'Royal National Park - A History', in Parks and Wildlife, 2(3-4), Centenary Issue, April, pp. 15-30

Readers Digest 1987. Readers Digest Book of the National Parks of New South Wales and the Australian Capital Territory, Surry Hills: Readers Digest.

Roberts, R. G., Rhys Jones and M.A. Smith, 1990. 'Thermoluminescence dating of a 50,000 year-old human occupation site in northern Australia'. Nature 345:153-156.

Robin, Libby 1994. 'Nature Conservation as a national concern: the role of the Australian Academy of Science' Historical Records of Australian Science, 10(1), 1-24.

Robin, Libby 1998. Defending the Little Desert: The Rise of Ecological Consciousness in Australia. Carlton: Melbourne University Press.

Robin, Libby and Tom Griffiths, 1994. Science in High Places. Consultancy Report to the Australian Alps Liaison Committee, Canberra, December 1994.

Rose, Deborah Bird 2004. Reports from a Wild Country, Sydney: UNSW Press

Runte, Alfred 1984. National Parks: The American Experience London: Bison Books (first ed. 1979).

Talbot, Lee M. and Martha Hayne Talbot (n.d.) 'Harold Jefferson Coolidge Jr. (1904-1985). Biography', http://cmsdata. iucn.org/downloads/h_j_coolidge_biography.pdf

Turner, Andrew unpub. 1979. 'National Parks in New South Wales, 1879-1979: participation, pressure groups and policy', $\mathrm{PhD}$ thesis, Australian National University.

Turner, Frederick Jackson 1893. 'The Significance of the Frontier (Chicago, 1893) in E. E. Edwards (ed.) Early Writings of Frederick Jackson Turner, Madison: University of Wisconsin Press, 1938

Webb, Leonard 1969. Impressions of Nature Protection in Europe Wildlife Preservation Society of Australia

Weideger, Paula 1994. Gilding the Acorn: A Critical History of the National Trust, London: Simon and Schuster. 


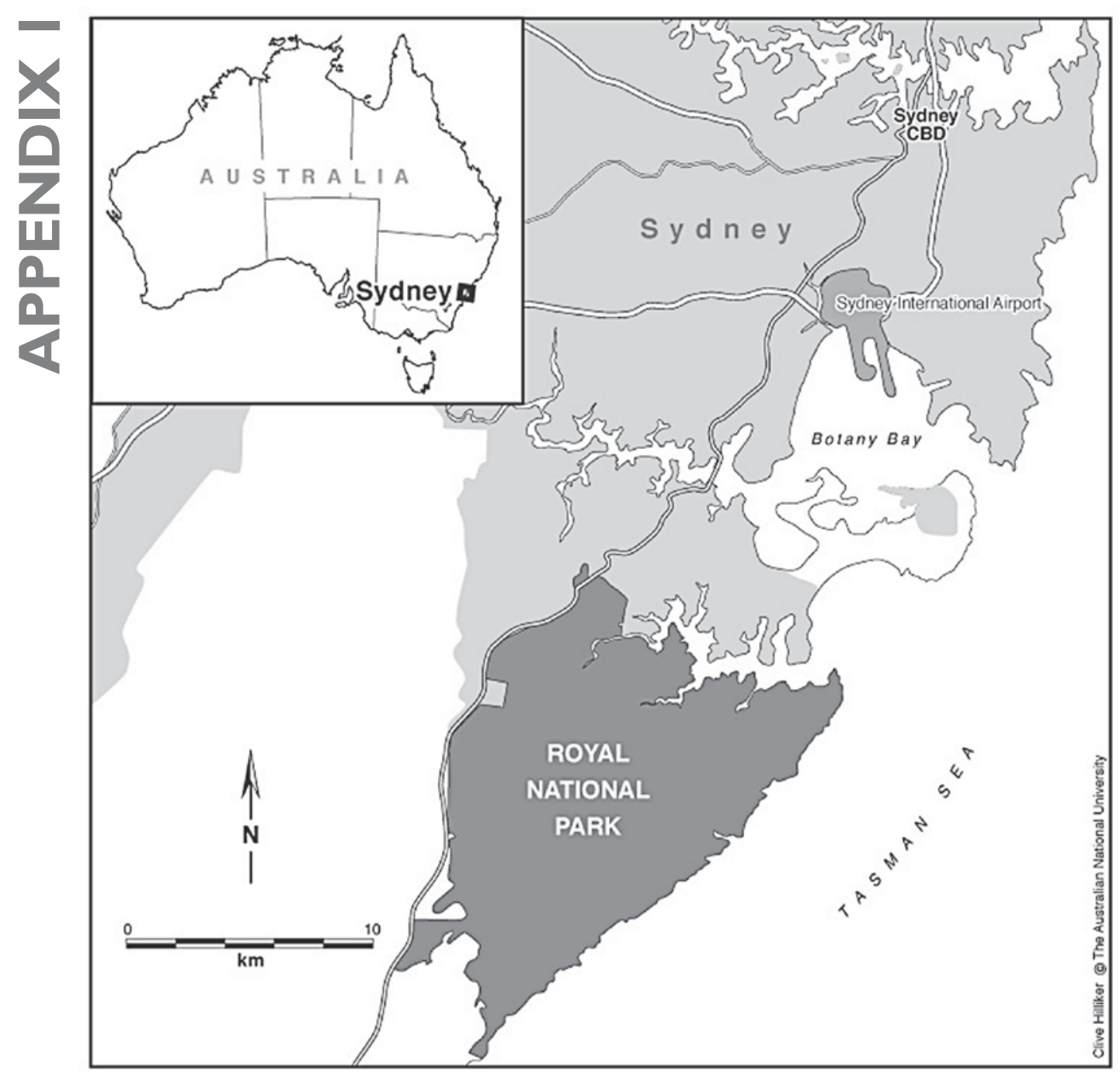

Location of Royal National Park, Australia. (Map: Clive Hilliker). 


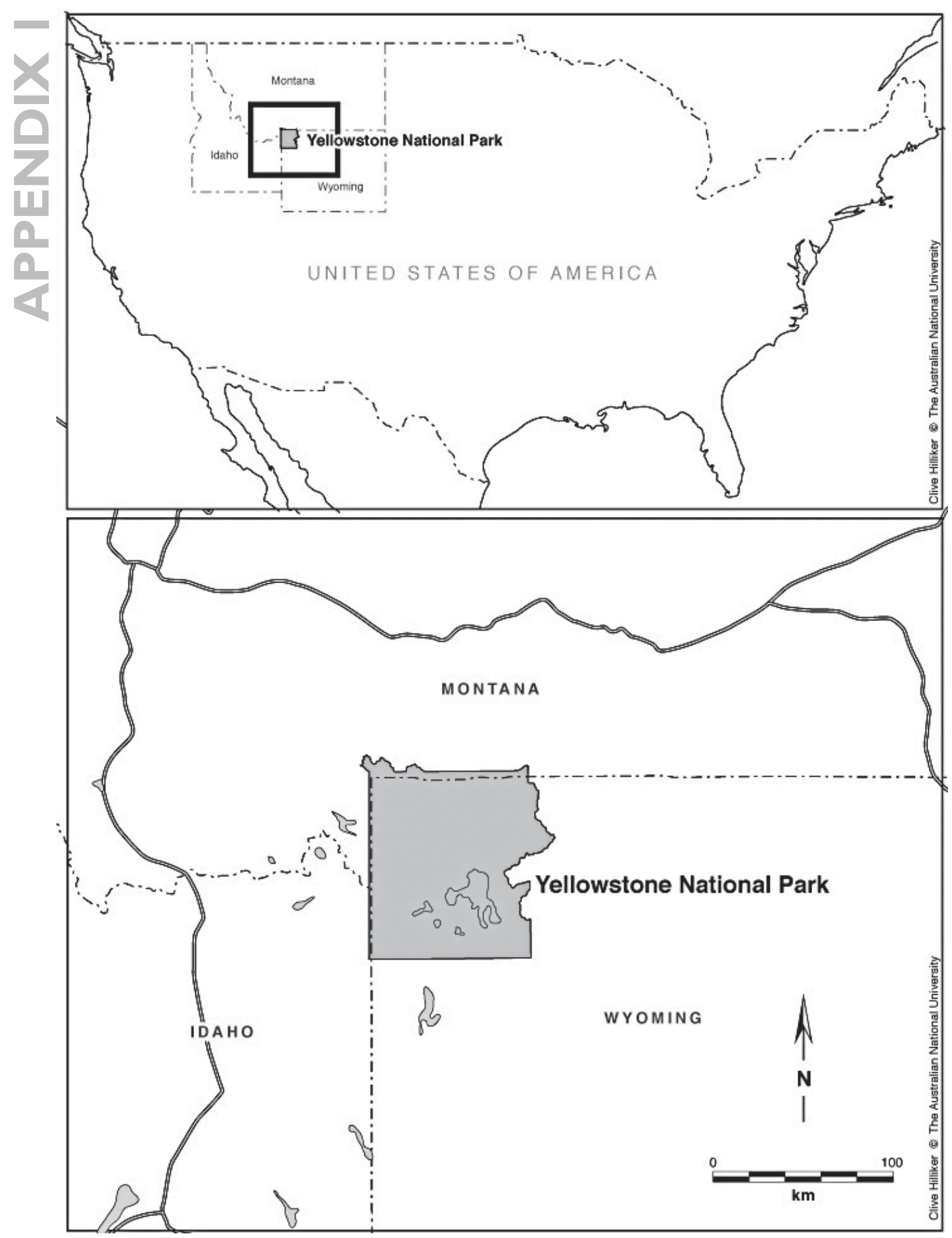

Location of Yellowstone National Park, United States. (Map: Clive Hilliker). 